\title{
Pre-school children's expressed technological volition during construction play
}

\author{
Kristina Thorshag ${ }^{1,2} \cdot$ Mona Holmqvist $^{1}$ D
}

Accepted: 29 October 2018 / Published online: 1 November 2018

(c) The Author(s) 2018

\begin{abstract}
Technology volition is the will to develop knowledge of, and use, the physical world to design products, processes and systems. The aim of this study was to contribute new knowledge of children's technology volition when they identify, build and improve technical constructions, and how teachers support this learning. Analysis focused on moments when children's volition was expressed in a construction activity. In total, eleven preschool teachers and 49 children, aged 4-5 years, from three preschools, participated. Data consists of video-recordings from four activities, two each in preschool A and B, showing children's expressed technological volition, as well as field notes about the teachers' preparations. Results show how differences among children's expressed volition is connected to their imagination of how materials can be combined to construct 'houses' and 'vehicles' from everyday objects. Building a house resulted in a focus on how to make the building solid and water resistant, and inspired children to learn about materials for different purposes in houses such as the floor, walls and an angled roof. Building a vehicle encouraged children to talk about speed, movements and fuel. Results show how children indicate and express their discernment of how materials are combined to create constructions, and how they discover ways in which materials change during the building process. For some of the children it was difficult to see the potential of a material other than its original use, while others used their imagination to find opportunities to use materials to make new objects.
\end{abstract}

Keywords Preschool · Construction technology $\cdot$ Volition

\section{Introduction}

To date, research on younger children and technology in education show that preschool and primary school staff have limited knowledge of children's home experiences with technology (Plowman et al. 2010). The authors also point out a lack of authentic activities, with fewer opportunities to develop children's awareness of the different cultural and work-related uses of technology. Teachers' ability to stimulate and offer materials affects

Mona Holmqvist

mona.holmqvist@mau.se

1 Faculty of Learning and Society, Malmö University, 20506 Malmö, Sweden

2 Faculty of Education, University of Gothenburg, Box 300, 40530 Gothenburg, Sweden 
children's interest in construction, and even if children do not seem to collaborate with others they observe others' actions and imitate them (Cremin et al. 2015). Beside these studies, there are a few papers that focus on technology learning from the age of eight (Turja et al. 2009; Mawson 2008; Bjurulf 2008), although most research in this field is primarily concerned with children from the age of 11 (Mawson 2008).

Mawson (2007 and 2008) argues that teachers' knowledge affects the content and image of technology as a subject. If teachers have limited technological knowledge they will struggle to find concepts to explain activities in the field, and children will develop a narrow view of technology. Many children have exposure to technology from their own leisure activities or their parents' occupations (Mawson 2013). When teachers take advantage of these experiences based on the children's interest, children develop their technology learning to a higher degree. Even if technology and science have different approaches-science to explain and understand the world, and technology as the design of socially-used tools (Nia and De Vries, 2016) — research results from science can contribute to our understanding of teaching technology in pre-school. Fleer et al. (2014) showed that preschool teachers with a 'sciencing attitude' support and enhance children in their science learning. They can provide science opportunities, both through their knowledge and by creating science areas where scientific challenges become discernible for the children. Language and preknowledge affect how children learn new concepts (Eshach and Fried 2005). Eshach and Fried (2005) argue that science should be taught in the early years because children are curious and want to examine, understand and reflect on their environment. Even if young children do not yet have the language, they experience and learn through their senses. Their attention to phenomena in their environment gives opportunities to learn by observing. In doing so, they need teachers who can answer their questions and share new concepts to enhance their knowledge. Technology as such is not a new phenomenon in pre-school and school, it has been a curriculumn subject in school for more than two decades (Solomon and Hall 1996)

Sundqvist and Nilsson (2016) have studied preschool teachers' views on elements of technology education in preschool. They found artifacts and activities were the focus when teachers expressed their views on technology in preschool. The teachers less frequently noted the importance of play and their own role, or how technology is defined and expressed in the syllabus for preschool. In fact, teachers considered themselves as providers of material to the children. They did not express any defined intentions about what aspects of children's knowledge they plan to develop through the activity. Bairaktarova et al. (2011) found differences in focus caused by differences in material. For example, puzzles encouraged children to complete a product while sandboxes stimulated their creativity. In the present study, we focus on what happens in preschool activities when children are involved in construction technology. Based on the research findings regarding teachers' attitudes (Sundqvist and Nilsson 2016), this study focused on children's construction technology activities in preschools to contribute new knowledge about teachers' and children's volitions during construction play. Construction technology has a long tradition in preschool (Bjurulf 2013), but knowledge of technology and the concepts used need to be discernible and highlighted for the children. Building and construction games can include anything from building huts to simple construction tools, and a variety of materials can be used depending on what is to be made. Building and construction games in preschool provide the opportunity to explore the balance and strength of various constructions and materials. Children's practice with different tools and models enables them to develop their language at the same time as they explore and discover phenomena in the world around them (Fleer 2000; Turja et al. 2009). Construction activities involve many subjects such as 
science, mathematics, language, technology and arts, and through construction children are exposed to the intersection of these areas, also typical in society and the environment.

Turja et al. (2009) and Parker-Rees (1997) define play as central in technology teaching at preschool. Different materials, such as recycled matter and bricks, were used in their study, and with the use of imagination, anything was considered possible. While playing, children experiment and work on getting to know the different kinds of materials and tools. Mitcham (1994) identified different concepts for defining technology in play. These include volition, knowledge, actions and objects. Knowledge refers to the information needed to carry out the activity. Technology as volition refers to the children's own willingness and intention to design products, processes and systems (Mitcham 2001). Volition is defined as the process of making and acting on decisions, or 'strength of will' (Corno 1993). In relation to technology, this is directed at designing technological solutions in different social contexts. The concept dates back to James and Dewey, and includes motivation, cognition and emotion in a broader self-regulatory system (Corno 1993). Motivation and volition differ, as the former is about intention while the latter enacts the intended actions. The 'arena of implementation' is where volition can be studied (Corno 1993). In society, there are several opportunities or obstacles to overcome. How people handle challenges depends on how they act and make decisions based on their volition. In this study, volition refers to 'the social nature of objects', or artefacts, used by human beings (Nia and De Vries 2016, p. 13) as defined by Mitcham (2001). Pre-school children's volition is studied using different kinds of materials either to create social constructions, or to use constructions to enact collaborative social activities.

Technical activities are carried out to produce something or use technological solutions. Objects are the artifacts used or created in the activity. When the children are unfamiliar with the material, it becomes more difficult for them to design a product (Milne and Edwards 2013). When the Swedish preschool curriculum Lpfö 98 (National Agency for Education 2016) was revised in 2010, technology was defined as an important area for preschool education. There have been several initiatives for in-service training since then, to develop teachers' abilities to teach technology in preschool. In Swedish preschools, play is an important activity for learning. Technology construction covers many different areas where children can explore technology through toys and try to construct their own mechanical solutions in playful ways (Bjurulf 2013). In games, children try different materials when they build and design, thereby gaining experience of technology and technical solutions. Swedish preschools aim to create opportunities for children to develop creativity and the ability to discover and develop technical solutions in everyday life (Ministry of Education 2010, p. 16). The Ministry of Education (2010) states that a physical environment is required in Swedish preschools, where unstructured material invites children to test, experiment and explore. It is also emphasized that the conversation about what is happening is important to challenge children to generate different solutions and improvements, and put what they do into words. Therefore, it is important for preschool teachers to discover and make visible new solutions together with the children. In the present study, we investigated the relation between different constructions built and the children's focus and learning opportunities in each case. The intention was to determine whether different constructions have implications for different technological and/or scientific learning opportunities. The approach was to study the learning objects and concepts visible in the children's and preschool teachers' activities in technology (Holmqvist 2011). The purpose of the study was to contribute new knowledge about children's volition in preschool play to identify, build and improve 
technical constructions. Two different kinds of constructions were studied: houses and vehicles. The focus of the analysis was children's use and handling of different materials, to understand their experiences of the materials' characteristics in different constructions. The research questions were:

1. How do teachers and children express volition before and during the building activity?

2. In what way do the children express an understanding of how different kinds of material can be connected and form new constructions?

\section{Participants and method}

In Sweden, preschool is a separate school for children aged 1-5 years. It is voluntary and municipalities are required to provide preschooling for children from the age of one. Preschool is regulated by the Education Act, and the National Preschool Curriculum (Swedish National Agency for Education 2016). The curriculum states that the preschool should stimulate children's development and learning, and offer the children secure care. Preschool staff should enable pedagogical activities for children to create, learn and explore. Play is an important part of the learning activities as well as creating, singing and cooperating with others (National Agency for Education 2011). In Swedish early childhood education, play is a strong foundation for activities. Play has been the main method used when planning learning activities in preschool, in Sweden as well as in other countries (Siraj-Blachford 2001). Preschools have a long tradition of working thematically, and to see learning and development as a whole. Education and teaching are fairly new concepts in Swedish preschool, clarified in the curriculum revision of 2010. Even though education has received greater emphasis, care is still essential for preschool. In line with this, Sundberg and Ottander (2013) found that even when preschool teachers have more content knowledge by the end of their teacher education, many still feel uncomfortable planning technology activities. This is because the content is reminiscent of teaching and school subjects. As the teachers do not have the tradition of teaching specific subjects, they feel unsure about how to plan and teach (Sundqvist and Nilsson 2016). Traditionally, teaching is associated with school and many Swedish preschool teachers do not feel comfortable using teaching as a concept for their professional work. In their latest report, the Swedish Schools Inspectorate (2016) stated that language and mathematical development should have a prominent role in the daily work of Swedish preschools. It was also stated that work with technology is important, although not the primary goal. Despite this, preschool staff often describe children as curious and wanting to explore and investigate phenomena. As spontaneity is important, teachers often work in a less conscious way to teach children technology. This could also be due to limited subject knowledge, which results in shortcomings in stimulating and challenging the children (Swedish Schools Inspectorate 2016).

Participants in the project were 11 preschool teachers and 49 children, aged 4-5 years old from two preschools on the west coast of Sweden (Table 1). Both preschools have a declared interest in working with technology. Preschool A is newly built and houses two sections. At this preschool, there will be ten age-homogenous departments for children between the ages of 1 and 5 years. The construction of the buildings with studios and squares, as well as the pedagogical base, is Reggio Emilia-inspired. The preschool yard is an extension of the house and is divided into different rooms for activities and sensory experiences. Two of the teachers are 'outdoor educators' who are also responsible for the 
Table 1 Participants and data

\begin{tabular}{|c|c|c|c|c|c|c|c|}
\hline Preschool & Children (N) & $\begin{array}{l}\text { Mean age of } \\
\text { children (Y) }\end{array}$ & $\begin{array}{l}\text { Video- } \\
\text { recordings }\end{array}$ & Field notes & Teachers $(\mathrm{N})$ & Meetings & $\begin{array}{l}\text { Group } \\
\text { interviews/ } \\
\text { teachers }\end{array}$ \\
\hline \multirow[t]{2}{*}{ A } & 1 & 4.7 & - & $\mathrm{x}$ & 2 & 3 & 2 \\
\hline & 9 & 4.7 & $39: 36$ min & $\mathrm{X}$ & 2 & & \\
\hline \multirow[t]{2}{*}{ B } & 7 & 4.5 & $23: 10 \mathrm{~min}$ & $\mathrm{x}$ & 5 & 3 & 5 \\
\hline & 3 & 5 & 43:51 min & $\mathrm{X}$ & 1 & & \\
\hline
\end{tabular}

Table 2 Constructions and material in the analyzed clips (1 min $20 \mathrm{~s}$ each)

\begin{tabular}{llll}
\hline Preschool & Construction & Situation 1 & Situation 2 \\
\hline A & Vehicle & $\begin{array}{c}\text { Pallets for trans- } \\
\text { porting goods } \\
\text { B }\end{array}$ & Wheels \\
\hline
\end{tabular}

teaching of technology. Preschool B is a 'nature preschool', consisting of a department of approximately 25 children between the ages of 1 and 5 years. Outdoor activities and environment are central, and incorporated daily. Pedagogy is directed towards environmental awareness for the children to develop an understanding and respect for all living things. At this preschool, there are four preschool teachers and a nursery. The teachers and children frequently work with construction technology, such as building houses with different kinds of materials. For example, children build huts with fresh branches, only to realize what happens when the leaves wilt and fall off.

Ethical aspects of the study were handled according to current ethical principles for research (Swedish Schools Inspectorate 2016). Parents were informed about the study in advance and signed a written consent. Children were informed about their right to not participate when the activities were recorded or to interrupt their participation.

Since children's volition during construction play is a complex phenomenon, mixed methods were used (Creswell and Clark 2007; Creswell 2014). We used statistical trends in combination with qualitative analysis of video-recorded observations to explain children's understanding of constructions expressed during building. Data consists of field notes, video-recorded observations, photographs and interviews (Table 1). Video-recordings were transcribed verbatim and statistically analyzed regarding word frequencies of teachers and children. The verbal output in the chosen video-clips $(4 \times 1 \mathrm{~min} 20 \mathrm{~s}$ from each activity) was analyzed quantitatively using Text Fixer to define the amount of spoken language during the activities for children and teachers respectively.

In the analysis, one of Mitcham's (1994) concepts, i.e. volition, was used to guide the sample to define situations showing the children's volition when engaged in construction technology play (Elvstrand et al. 2012). The units of analysis consisted of four video-recordings analyzed to find the moment when a child's volition was expressed. This resulted in four clips each, from two different groups at each pre-school (A and B), with a duration of $1 \mathrm{~min}$ and $20 \mathrm{~s}$. The clip started when one or more child expressed technological volition. To make the activities possible to compare, the recordings ended at the same time in all cases: after 1 min and $20 \mathrm{~s}$. The time slot was decided based on an analysis of the children's average active collaboration after the initial initiative. At preschool A, the 
children constructed vehicles, while huts were constructed at preschool B. All four clips are recordings of situations in which, based on Mitcham's (1994) definition, the children have a shared volition to create a construction. The clips were selected to afford an analysis of the relationship between volition and knowledge development. Table 2 shows constructions and materials used.

Teachers' expressed volitions were documented by field notes before the activity and during planning meetings. Video-recordings were used to capture the teachers' volition during the children's activities.

\section{Results}

Teachers' volition was expressed in three ways: by their preparations for the activities, by offering material for the children to use during the activity, and by their participation in the activity. Analysis of the video-recordings shows the materials the teachers prepared for the children. The result of this analysis is presented in Table 3.

The teachers prepared for activity A by reading a fairytale about Rainbow-land. They showed a soft toy mouse who wanted to go to Rainbow-land, but did not have a vehicle. In activity $\mathrm{B}$, the teachers continued working with the theme 'homes and housing' where the children were learning about urban and rural living, wild and tame animal nests, and national and international housing, with a focus on construction. This theme was ongoing for the year, and the study was conducted in the middle of this work.

While constructing a vehicle (A), the teachers offered several different materials, such as: wheels, pallets (rough wooden frame used for transporting goods), logs, pipes for electrical wiring including stands, ropes, stand for lampshade, wire basket, cable-drums, building blocks, and carpet. The material for building a hut consisted of: tarpaulins, ropes, pegs, small clamps, and shower curtain rings. During the activities, teachers expressed their volition by commenting on the children's activities. The teachers also supported the children's construction activities by clarifying and enhancing the children's intentions. Comments such as: "How does this work?"; "You might use this to make it more solid,", or asking in what way the material contributes to the construction (A1), were frequently used.

Table 3 Material offered to the children initially

\begin{tabular}{|c|c|c|c|}
\hline A1: Vehicle 1 & A2: Vehicle 2 & B1: The hut in the fence & B2: The hut in the cypress \\
\hline $\begin{array}{l}3 \text { pallets for transporting } \\
\text { goods } \\
\text { Log } \\
\text { Pipes for electrical wiring } \\
\text { Stands for the pipes } \\
\text { Boards } \\
2 \text { bicycle wheels } \\
\text { Cable drums } \\
\text { Stand for lampshade } \\
\text { Carpet } \\
\text { Building block }\end{array}$ & $\begin{array}{l}2 \text { bicycle wheels } \\
\text { Pallet for transporting } \\
\text { goods } \\
\text { Rope } \\
\text { Pipes for electrical } \\
\text { wiring } \\
\text { Pipe couplings } \\
\text { Stands for the pipes } \\
\text { Building block } \\
\text { Log } \\
\text { Boards } \\
\text { Cable drum } \\
\text { Stand for lampshade } \\
\text { Wire basket } \\
\text { Mat }\end{array}$ & $\begin{array}{l}1 \text { tarpaulin } \\
\text { Ropes } \\
\text { Sheet } \\
\text { Quilt }\end{array}$ & $\begin{array}{l}2 \text { tarpaulins } \\
\text { Ropes } \\
\text { Pegs } \\
\text { Small clamps } \\
\text { Rings for shower curtains }\end{array}$ \\
\hline
\end{tabular}




\section{Excerpt 1 (A1):}

Sam: Here's a blanket

Tom: Good. A carpet [puts it on the ground in front of the car]

Erik: A potty [puts a wire basket on top]

Ben: And a toilet. [Throwing a cable drum on the side of the vehicle]

Teacher 1 [the kids throw on different objects]: But listen, now you're just throwing things. Can you go to the toilet then if it is on the wheel?

Eric: A saucepan, a saucepan to cook. A saucepan so you can have food

Tom: This... can sit on the wheel. There, just

Teacher 1: There may be a new version, who knows.

Another way identified to enhance the children's volition was to take the role of the mouse supposed to be driving the vehicle (A2), and ask the children how it would be possible for the mouse to do this.

Excerpt 2 (A2):

John: This is not a wheelchair, it's a unicycle and you cannot kick the tires

Adam: Then it will get stuck

John [to Carl]:... and you know, just because you sat there, the tire fell off. This is for just little stuff.

Carl: Smutt! Smutt! [The mouse's name] Come here.

Teacher 2 [with the mouse, Smutt, in her hand]: How should I do, Calle?

Carl [shows with his hand that Smutt can sit on the cable drum]: and then a roof.

Teacher 2 [acting Smutt]: I need some roof. It's cold. I need a little more.

[A child comes with the steel frame to the ceiling lamp and tries to place it on top of the pallet and the cable drum.]

Jesper: He can have it around!

Carl: I know!

Mary: It may be around the mouse.

In B2, constructing the hut, the children asked the teacher to help them build the hut in a way they had collectively agreed on based on a design they had presented to the teacher. This was also the case in B1, with a difference in joint volition among the children. Two girls participated in B1, however, as one of them did not show any volition to act, the teacher tried to involve her in the activity.

\section{Excerpt 3 (B1):}

Teacher: Should I stay here now and hold?

Jill: Yes

Teacher: Where should I tie it? Jill? How will you get it now? Britt, do you have any ideas?

Britt: We can only put it, like... [shows with her hand on the fence]

Teacher: Here around too?

Britt: Yes, like [shows with her hand]

Teacher: Do you think it works with this string? Is it good length of the string?

[Keeps the rope over the fence] Does this feel good? Or do we need to get more material?

Britt: Yes, we can take this [shows another rope]

Teacher: Is it longer? Should we try? 
[Teacher and Britt work together.]

Britt: So then

Teacher: Of course. [Britt pulls the string into the eyelet] Then we'll see.

[It's hard to position the rope as the tip has frayed.]

Britt: You can take this one. [Britt turns and takes the other end of the string. Once the tarpaulin is stretched to reach the fence, Jill tries to tie a string around the fence] Teacher: I'm holding here... [Britt gets the string in through the eyelet] Did it work out well? Was it longer?

Britt: Yes

Teacher: Was it a little longer? Can it tie now? Does it work?

Britt: Yes, longer [notice that it's too short to tie] I'll go and get another string.

Teacher: You go and get another string.

Jill: Me too

The teacher thus showed a shared focus on building the hut as well as enhancing one girl's volition. In Table 4, the difference in talk-time for B1 is due to the teacher's ambition to involve one of the children in the design activity, by explaining and clarifying what was happening. She did not succeed in this, as the child's interest was captured by the material itself (a rope), and not how it could be used. This child had limited interest in putting materials together to make a construction. In the other group, the children were asking the teacher to act based on their own decisions:

\section{Excerpt 4 (B2):}

Niclas: But we need another step [a branch higher up to tie the rope]

Kevin: Yes

Kevin: I'm too short! I think I'll... Teacher, we need help!

Teacher: Mm. But have you thought about how to do it? Because you did not really agree, or?

Niclas: Yes, we have

Kevin [struggling up in the cypress]: I do not reach!

Teacher: Tell me once again how you thought it would be then

Niclas: Like a big $\mathrm{X}$ here. A rope like this, shhhh, and a rope like that shhhh [shows with his hand how the ropes should sit] and then we set the tarpaulin in front.

Kevin: Niclas, did you think it's like this: and shhht, shhht [shows with his hand]

Niclas: Well, Shh, shh

Kevin: Niclas, keep in mind that this is not just your idea, Niclas. We all have to come up with, everyone must come up with an idea that we can do... we have to come up with the same idea.

Niclas: Should we do it or?

Teacher: So you mean so you're in agreement?

Table 4 Number of words uttered in the situations ( $1 \mathrm{~min}$ $20 \mathrm{~s}$ per clip)

\begin{tabular}{llll}
\hline Situation & Teachers & Children & Total \\
\hline A1 & 66 & 115 & 181 \\
A2 & 51 & 108 & 159 \\
B1 & 87 & 32 & 119 \\
B2 & 56 & 146 & 202 \\
Total & $260(39 \%)$ & $401(61 \%)$ & $661(100 \%)$ \\
\hline
\end{tabular}


Kevin: What do you say, Otto?

Otto: Yes!

Kevin: Do you know what I'm saying? Yes!

Niclas: We do it!

During the activities captured in the clips, verbal output from the teachers and children was analyzed to capture relationships between teacher and child volition. Table 4 presents a quantitative analysis of words uttered. It shows that in all design activities, except one, the children were more talkative than the teachers.

The children's volition in A1 was expressed by finding several different materials, imagined to represent parts of a vehicle for imaginary play as a car for a soft toy mouse. The children $(n=7)$ fetched different materials and explained what part of a vehicle each represented. For example, a cable drum was a toilet, and a wooden pallet for transporting goods represented the motor. All materials were put on top of each other, building a heap of objects rather than a construction. The teacher finally commented on this by saying: "But listen, now you just throw things!" The children seemed to see the parts of a construction, but were not able to connect them to each other making a solid vehicle. In A2, almost the same group of children $(n=5)$ started a new activity building a vehicle. They used the same material, but the design seemed to have taken form and guided their building. To create a construction, parts were chosen to fit into the whole picture of the kind of vehicle they intended to make. Initially, one boy showed how the vehicle should be used. Another boy interrupted to say that it should not be used as a wheel-chair by the children, but by a small mouse. He also noted that the vehicle was not sturdy. They then constructed the driver's seat together using the cable drum. They designed the roof to be solid, offered enough space in the vehicle for the mouse as well as ensuring it was easy to get in and out of. During activity A2, the material was used to form a whole. The children integrated the material as parts, which were repurposed when used to form a vehicle, e.g., a rough wooden platform for transporting goods (a pallet) became the car body.

For the hut building, two activities were carried out by two different groups of children. In B1, one of the children showed the teacher how to tie a tarpaulin, symbolizing a roof, to a fence with a rope. The rope was too short so she fetched another. Another child was playing with another rope, but did not offer this one. She was fascinated by the rope itself, playing with it beside the building area. She also tried to tie the rope to the fence, however she did not connect it to the tarpaulin to make a hut. Activity B2 consisted of three children who had decided on a joint design of a hut built through linking with a cypress. They asked the teacher to help them tie the ropes as an $\mathrm{X}$ as they were too short to reach the top of the plant. This group had revised their way of building, as they had previously tried to build in other, less sustainable ways (leaves falling of branches).

The analysis shows how materials were used differently, as parts with a focus on the material per se (material foreground), or as representations of parts of another construction (construction foreground). The difference in seeing parts or a whole seemed to affect children's abilities to construct. Children with a strong focus on a single material showed less volition to design constructions. They seemed to be committed to work with the function of the material as such, and not as a part of a design. Activities A1 and A2 show how the same children, on two different occasions, developed their construction strategies. Time and repeated opportunities to build seemed to develop their ability to transform the use of a single material into part of a construction, connected to other materials. Through this, they tested, retested and improved their construction. In A1, their volition decreased and they 
stopped to design. However, with enhanced knowledge in A2, their volition increased and ensured they fulfilled their intentions to design a vehicle for the toy.

Differences in learning opportunities were found depending on what constructions the children were supposed to design, and the material used. Differences in use implied a different focus expressed and learnt when designing. Building a house resulted in a focus on how to make the building solid and water resistant, and inspired the children to learn about different kinds of material for different purposes in a house, such as the ground, floor, walls and the importance of tilting the roof to get rid of water and snow. Building a vehicle inspired the children to talk about speed, movements and different kinds of fuel. The results show that different kinds of construction design can be used to create different foci in learning during play in preschool. The results also show how knowledge impacts on volition during the construction activities, which can be used to strengthen technological education in pre-school and highlight its cross-curricular potential.

\section{Discussion and conclusions}

Two research questions were addressed in this study. The first one was about how teachers and children express volition before and during a building activity. The teachers' volition was expressed during their preparations for what they wanted the children to design, offering the children materials that they considered appropriate for construction purposes. Their choices of material are strongly influenced by social and cultural understanding of designing constructions in a human society, a normative perspective (De Vries 2005) not necessarily shared by the children. The results of our study support the findings of Sundqvist and Nilsson (2018), regarding teachers' beliefs about technology in pre-school. During the construction activity, teachers in our study acted as providers for the children's activities by setting the scene with materials that held potential for their use. This means they also set some limitations for the children in their design of constructions. At the same time, the children were more free in using the material, addressing the second research question: In what way do the children express an understanding of how different kinds of material can be connected and form new constructions? Some children used the material randomly and did not seem to have a plan or model of what to build, while others had a clear picture of what they wanted to construct. The children viewed the material in different ways, either seeing the material as foreground or regarding it as pieces in a construction. The children's volition differed regarding the offered material, where some expressed volition for using the material to make a construction while others showed volition for exploring the material as such.

We also found a relationship between the constructions built and scientific knowledge. Building a vehicle resulted in discussions beyond mere building and included consideration of construction stability versus speed. This is in line with the study by Bairaktarova et al. (2011), who found a relationship between a material and its generic abilities developed during the activity. Swedish preschool rests on a long tradition of seeing care for children as the primary goal. The shift from seeing preschools as having a primary role of caregiving, to an institution for teaching and learning, has not yet been realized. Teacher anxiety about developing a school-like atmosphere in preschools limits their ambitions to explicitly develop children's knowledge by playful instruction. However, we argue that construction technology could be used in preschools as a tool to develop knowledge in different areas of technology. Depending on the technical challenges given to children, they will have to 
focus on different concepts, important for construction. The function of the construction will affect the knowledge required. To construct a vehicle requires consideration of energy and speed. Building a house requires knowledge about sustainability. We need more knowledge about children's learning and understanding of constructions, and how preschool teachers can use construction technology to inspire children to develop different aspects of technology knowledge important to understand objects in their environment. This study of the volition of teachers and children shows a relationship between knowledge and volition, as children showing less understanding of the activity did not express or enact any volition. Furthermore, the teachers' volition was limited to making it possible for the children to build, as they did not explicitly instruct children about the projects or foster discussions about the constructions required.

Acknowledgements This study is part of the Swedish National Research School on Communication and Relations as Foundations for Early Childhood Education (FoRFa), funded by the Swedish Research Council (Grant No. 729-2013-6848), for which we are grateful. We thank Michelle Pascoe, Ph.D., from Edanz Group for editing a draft of this manuscript.

Open Access This article is distributed under the terms of the Creative Commons Attribution 4.0 International License (http://creativecommons.org/licenses/by/4.0/), which permits unrestricted use, distribution, and reproduction in any medium, provided you give appropriate credit to the original author(s) and the source, provide a link to the Creative Commons license, and indicate if changes were made.

\section{References}

Bairaktarova, D., Evangelou, D., Bagiati, A., \& Brophy, S. (2011). Early engineering in young children's exploratory play with tangible materials. Children Youth and Environments, 21(2), 212.

Bjurulf, V. (2008). Teknikämnets gestaltningar. En studie av lärares arbete med skolämnet teknik. Doktorsavhandling. [Technology configurations. A study of the work of teachers in the school subject technology. Dissertation.] Karlstad: Karlstad University Studies 2008:29.

Bjurulf, V. (2013). Teknikdidaktik $i$ Förskolan. [Technology Education in Pre-school.] Lund: Studentlitteratur.

Corno, L. (1993). The best-laid plans: Modern conceptions of volition and educational research. Educational Researcher, 22(2), 14-22.

Cremin, T., Glauert, E., Craft, A., Compton, A., \& Stylianidou, F. (2015). Creative little scientists: Exploring pedagogical synergies between inquiry-based and creative approaches in early years science. $E d u$ cation, 3-13, 43(4), 404-419.

Creswell, J. W. (2014). A concise introduction to mixed methods research. Thousand Oaks, CA: Sage.

Creswell, J. W., \& Clark, V. L. P. (2007). Designing and conducting mixed methods research. Thousand Oaks, CA: Sage Publications Inc.

De Vries, M. J. (2005). The nature of technological knowledge: Philosophical reflections and educational consequences. International Journal of Technology and Design Education, 15(2), 149-154.

Elvstrand, H., Hellberg, K., \& Hallström, J. (2012). Technology and gender in early childhood education: How girls and boys explore and learn technology in free play in Swedish preschools. In PATT 26 conference, technology education in the 21st century, Stockholm, Sweden, 26-30 June, 2012 (pp. 163171). Linköping, Sweden: Linköping University Electronic Press.

Eshach, H., \& Fried, M. N. (2005). Should science be taught in early childhood? Journal of Science Education and Technology, 14(3), 315-336.

Fleer, M. (2000). Working technologically: Investigations into how young children design and make during technology education. International Journal of Technology and Design Education, 10(1), 43-59.

Fleer, M., Gomes, J., \& March, S. (2014). Science learning affordances in preschool environments. Australian Journal of Early Childhood, 39(1), 38-48.

Holmqvist, M. (2011). Teachers' learning in a learning study. Instructional Science, 39(4), 497-511.

Mawson, B. (2007). Factors affecting learning in technology in the early years at school. International Journal of Technology and Design Education, 17(3), 253-269. 
Mawson, B. (2008). Children's developing understanding of technology. International Journal of Technology and Design Education, 20(1), 1-13.

Mawson, W. B. (2013). Emergent technological literacy: What do children bring to school? International Journal of Technology and Design Education, 23(2), 443-453.

Milne, L., \& Edwards, R. (2013). Young children's views of the technology process: An exploratory study. International Journal of Technology and Design Education, 23(1), 11-21.

Ministry of Education. (2010). Preschool in development-The background to the changes in the preschool curriculum. Stockholm: Ministry of Education.

Mitcham, C. (1994). Thinking through technology: The path between engineering and philosophy. Chicago: University of Chicago Press, cop.

Mitcham, C. (2001). Philosophizing about technology: Why should we bother. Ethics, 17. Available at: https://ethix.org/2001/06/01/philosophizing-about-technology-why-should-we-bother. Accessed 4 Dec 2012.

National Agency for Education. (2016). Curriculum for preschool. www.skolverket.se. Accessed 4 Dec 2012.

Nia, M. G., \& De Vries, M. J. (2016). 'Standards' on the bench: Do standards for technological literacy render an adequate image of technology? Journal of Technology and Science Education, 6(1), 5-18.

Parker-Rees, R. (1997). Learning from play: Design and technology, imagination and playful thinking. In IDATER 1997 Conference. Loughborough: Loughborough University.

Plowman, L., Stephen, C., \& McPake, J. (2010). Supporting young children's learning with technology at home and in preschool. Research Papers in Education, 25(1), 93-113.

Siraj-Blachford, J. (2001). Emergent science and technology in the early years. Paper presented at the XXIII world congress of OMEP, Santiago Chile July 31st to 4th August 2001.

Solomon, J., \& Hall, S. (1996). An inquiry into progression in primary technology: A role for teaching. International Journal of Technology and Design Education, 6(3), 263-282.

Stafström, S. (2017). Good research practice. Stockholm: Swedish Research Council. Available on internet: https://publikationer.vr.se/produkt/god-forskningssed. Accessed 4 Dec 2012.

Sundberg, B., \& Ottander, C. (2013). The conflict within the role: A longitudinal study of preschool student teacher's point of view. Journal of Childhood Teacher Education, 34(1), 80-94.

Sundqvist, P., \& Nilsson, T. (2016). Technology education in preschool: Providing opportunities for children to use artifacts and to create. International Journal of Technology and Design Education, 1, 1-23.

Sundqvist, P., \& Nilsson, T. (2018). Technology education in preschool: Providing opportunities for children to use artifacts and to create. International Journal of Technology and Design Education, 28(1), 29-51.

Swedish Schools Inspectorate. (2016). Förskolans pedagogiska uppdrag. Stockholm: Skolinspektionen.

Turja, L., Endepohls-Ulpe, M., \& Chatoney, M. (2009). A conceptual framework for developing the curriculum and delivery of technology education in early childhood. International Journal of Technology and Design Education, 19(4), 353-365. 